\title{
Large Lymphocyte Count
}

National Cancer Institute

\section{Source}

National Cancer Institute. Large Lymphocyte Count. NCI Thesaurus. Code C158236.

The determination of the number of large lymphocytes present in a sample. 